\title{
Strategic Human Resource Practices and its Impact on Performance towards Achieving Organizational Goals
}

\section{Md Yusuf Hossein Khan}

PhD Researcher in Tourism, University of Algarve, Portugal; Assistant Professor, College of Tourism and Hospitality Management, International University of Business Agriculture and Technology, Bangladesh

\begin{abstract}
The potential use of skills, knowledge and competencies of employees in the organization would help to improve organizational performance. Certainly, the necessity of strategic human resource management in a business cannot be undermined as human resource management practices and policies influencing work, attitudes and performance of employees. Having said that human resource policies are focused on many essential practices and in turn, can positively impact organizational performance, such as human resource planning, recruitment, selection, training and development, compensation, performance management and employee relations.

Once an organization believes to determine its upcoming mission and willing to achieve them, it is then rely on the employees, as they will be the key to do the necessary work geared towards achievement of the organizational goal and success through their performance. This is where the importance of strategic human resources of an organization can be seen. Without any doubt, it can be said that the success of a business depends on its human resources and the development and inspiration process of the workers in the organization plays an important role in the organizational success. Human resource strategies aims to look into and examine the human resource functions within the company in line with the business strategies of an organization.

Despite the facts mentioned above using different literatures, books, articles, reports, surveys, this paper examines the outcomes of strategic human resource practices within an organization's performances. The main objective of this paper was to identify whether strategic human resource practices play any positive roles on organizational performances. This paper will form awareness within employees, potential organizations, government and private sectors regarding the strategic human resource practices.
\end{abstract}

Keywords: Strategic, Human Resource, Performance, Organization, Management, Development.

JEL Classification: J24, D2, F63.

(C) The Author, 2018. This article is published with open access at Sumy State University.

\section{Introduction}

Strategic human resource management is the practice of attracting, developing, rewarding, and retaining employees for the benefit of both the employees as individuals and the organization as a whole. The best outcome of the strategic human resource practices is when an organization HR department that perform strategic human resource management do not work independently within an organization but interact with other departments within an organization in order to understand their goals and then create strategies that align with those objectives, as well as those of the organization. As a result, a clear positive change can be visible while complying with the organizational goal as strategic human resource management practices supports in achieving these goals.

Without any double, in the current business world, human resource management plays a vital role within the organization by setting up many important policies and practicing the essentials. Massive changes on the trends of globalizations came as a challenge for human resource management, which are required to be handled effectively for managing diverse workforce. Strategic human resource management is one of the most important aspect of HRM practices that facilitates in implementations of HRM policies in relation to accomplish organizational goals (Mathis and Jackson, 2008).

Over the past decades, many researches have been conducted so far to show the effect of strategic HRM practices on organizations performance. In previous researches, it has been showed that effective use of HR practices improve firm performance by increasing productivity of employees, decreasing turnover rates and increasing sales and profits of the company (Huselid, 1995; Becker and Gerhart, 1996; Delery and Doty; 1996). When the debate take place on HRM and Strategic HRM, Strategic HRM has a clear focus on implementing 
strategic change and growing the skill base of the organization to ensure that the organization can compete effectively in the future (Holbeche, 2004). SHRM facilitates the development of a human capital that meets the requirements of business competitive strategy, so that organizational goals and mission will be achieved (Guest, 1987).

\section{Literature Review and Critical Analysis}

\section{Human Resource Management}

The task of human resource management of a company is recruiting, training and finally motivating them so that it can achieve its goal. It also involves in solving the problem arise among the employees. In simple words, Human resource department deals with the employees and their issues. The production of any product or service and the smooth operation of an organization cannot be done alone with the capital. Another major requirement is human resource. Product or service may produce by machines and technology, but requires the contribution of a human being. The most influential element is manpower for any sort of production (Huselid, et al, 2015).

Organizations need different types of human resources. Some organizations manage their lower level staffs or workers in the same way they deal with their higher level staffs but each group is recruited differently and selected according to different criteria. They attends different training programs and is paid differently. If a company is focused on customer service then it will need to build customer service skills and behaviors into all customer-oriented jobs, but your specific strategy of recruitment, selection, training and rewards for different positions (Torrington, et al, 2011).

There is certain human resource strategy, which has a direct impact in implementing the human resource policy of an organization. Human resource strategy is related with the type of the company, objective of the company and finally mission and vision of the company. Human resource activities is the task where strategies are needed to be set in a way which ensure the proper utilization of the resources, tools which can ensure maximum productivity for the organization (Marvel, 2011).

"Human resource strategies can be stimulating to produce and satisfying to display, but how can we make sure that they are implemented?" (Torrington, Hall and Torrington, 2011). According to Marvel (2011) "Human resource strategies is the best way to inspire the workers and ensure maximum productivity. The way of improving the productivity of the employees is the development of several types of financial and non-financial aid, such as bonuses and appreciation. Boxall, et al, (2007) stated that these often serve as a source of inspiration for employees to work with more effort and attain the proposed incentives".

\section{Human Resource Manager and Performance}

Human resource manager plays a vital role by making the organizational strategy, which can lead the organization to success or failure. So a perfect strategy is needed to be set by considering the type of business or company. It should make considering two things and these are whether it supports our business or not. And second consideration is that is it a perfect plan that can be implementable (Noe, et al, 2007). Campbell's (2011) theory says that human resource strategies impact in performance can be measured directly by using different tools. Schmalz (2012) says that the theory states that the evaluation from a supervisor, peer, staffs, a simulated work sample or hard criteria should be taken in focus. Besides the entire evaluation process should not be in one person's hand. That means a systematic way should be followed for it. As mentioned by Hazarika (2014) there might be some situational barrier or constraint, which might be the reason behind the wrong appraisal of the performance, and at the same time, this can be the reason for wrong strategy setup.

The literature reveals that studies into the human resource strategies performance have not determined a specific and precise meaning for the construction of organizational performance (Delahaye, 2011). Some studies have used mathematical measures and calculated firms' performance, such as employee needs, customer needs, executives' observations about the company's performance, employee behavior towards organization, and other behavior aspects (Mondy, et al, 2015). Other studies reference, which includes various subjective measures for evaluating firms' performance, such as financial and historical data. As a result, Noe, et al, (2007) said that there are certain rules concerning organizational performance, and researchers use many indicators or variables to evaluate this construct.

According to Milkovich (2006), the success from the human resource department of an organization should be sustainable. That means it is not imitable by the competitors of that industry. The main rationale behind is that 
its appearance is not visible like other factors of production (Harvey, 2012). For ensuring maximum productivity of human resource management, Prasad, et al, (2013) said it is needed to be done in a well acceptable manner.

\section{Strategic Human Resource Management}

The necessity of strategic human resource management in a business cannot be undermined (Mayo, 2012). As suggested by Campbell and Moyers (2013) it is due to the fact that human beings are the driving force behind any organization. In this respect, organizations must be able to implement well-planned and well-thought out strategic human resource ideas that will be implemented to coordinate as well as to channel the human capital into increased productivity. According to Torrington, et al, (2011) a concrete human resource strategy will allow a business to have a good understanding with its workers and to work peacefully, also in a mutually beneficial manner with its host community.

Research between strategic human resource management and productivity has influenced the academic and workers debate for more than three decades. However, most research and publications in the field of human resource management have given the concept in terms of individual practices. According to Noe et al. (2007), refers human resource management practices and policies influencing work, attitudes and performance of employees. As stated by Marvel (2011) they are focused on many essential practices and in turn, can positively impact organizational performance, such as human resource planning, recruitment, selection, training and development, compensation, performance management and employee relations.

\section{Management Strategy and Performance Outcome}

These practices are shaped by seven human resource management practices; these practices are expected to increase organizational performance and enable the organization to gain a competitive advantage (Huselid, et al, 2015). Such practices are detailed as follows (Boxall, Purcell and Wright, 2007):

\section{Human Resource Management Practices}

- Employment security.

- Selective hiring of new personnel.

- Self-managed teams and decentralization of decision-making

- Comparatively high compensation contingent

- Extensive training.

- Reduce status distinctions and barriers

- Extensive sharing of financial and performance

Figure 1. Human Resource Management practices

Source: Boxall, Purcell and Wright, 2007

The pattern of relationship between human resource management and performance is shown in Figure 1. This model is reflected elaborately the connection existing from business strategies to organizational performance measured by financial indicators. 


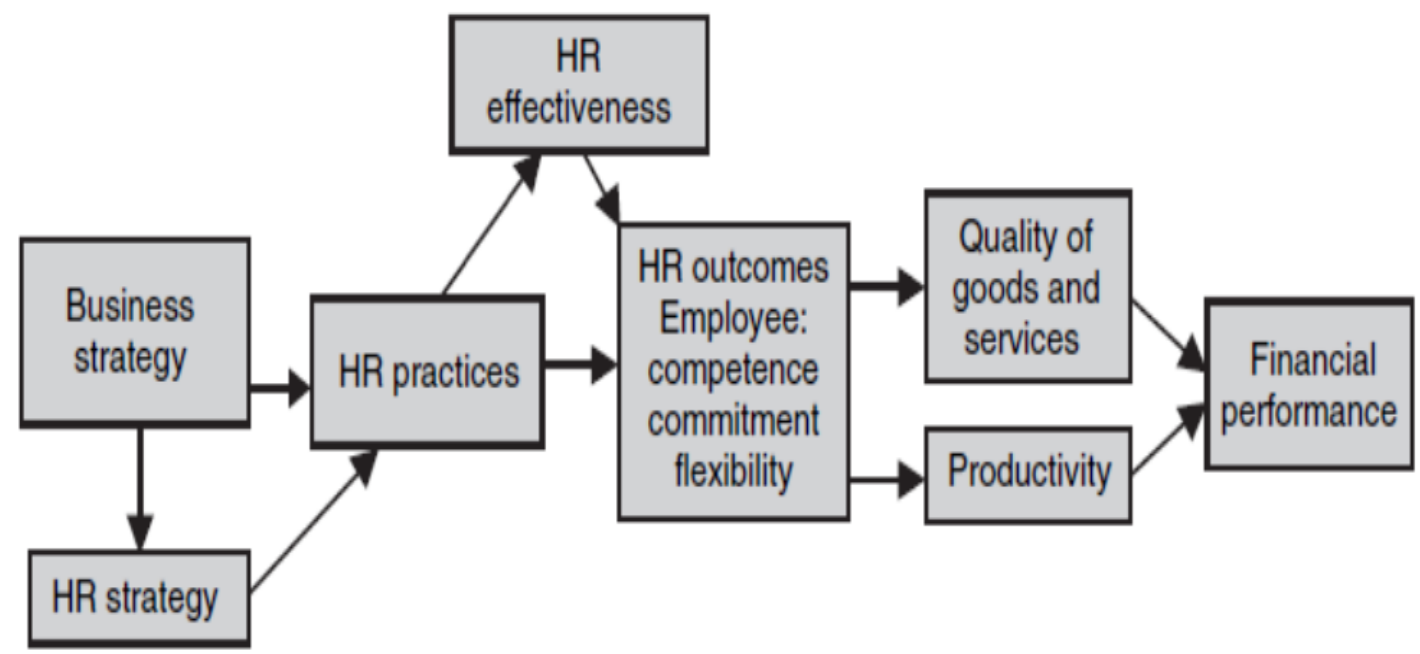

Figure 2. The Relationship between Strategic HRM and Performance

Source: Noe, et al, 2007

One of the ways that human resources strategies are helpful to an organization is the way including a perfectly implemented strategic human resource plan, which will help an organization to attain its goals (Armstrong and Armstrong, 2009). Schmalz (2012) said that when a company sets missions hoping to achieve, it is the employees who will do the necessary work geared toward the achievement of the organizational goal. This is where the importance of strategic human resources in an organization can be seen (Delahaye, 2011). As mentioned by Hazarika (2014) since the human resource department will find out the key areas in the company that requires human resource. This department will also carry out the mandatory steps toward the selection of the ideal candidates who cannot only fill the vacancies but can also help the company achieving its mission, vision and other long-term or short-term goals (Farazmand, 2007).

In a research of human resource management-performance, the performance outcomes of human resource management can be viewed in different ways. Human resource management researchers have mostly referred to Dyer and Reeves (2009) classification of performance outcomes following the given:

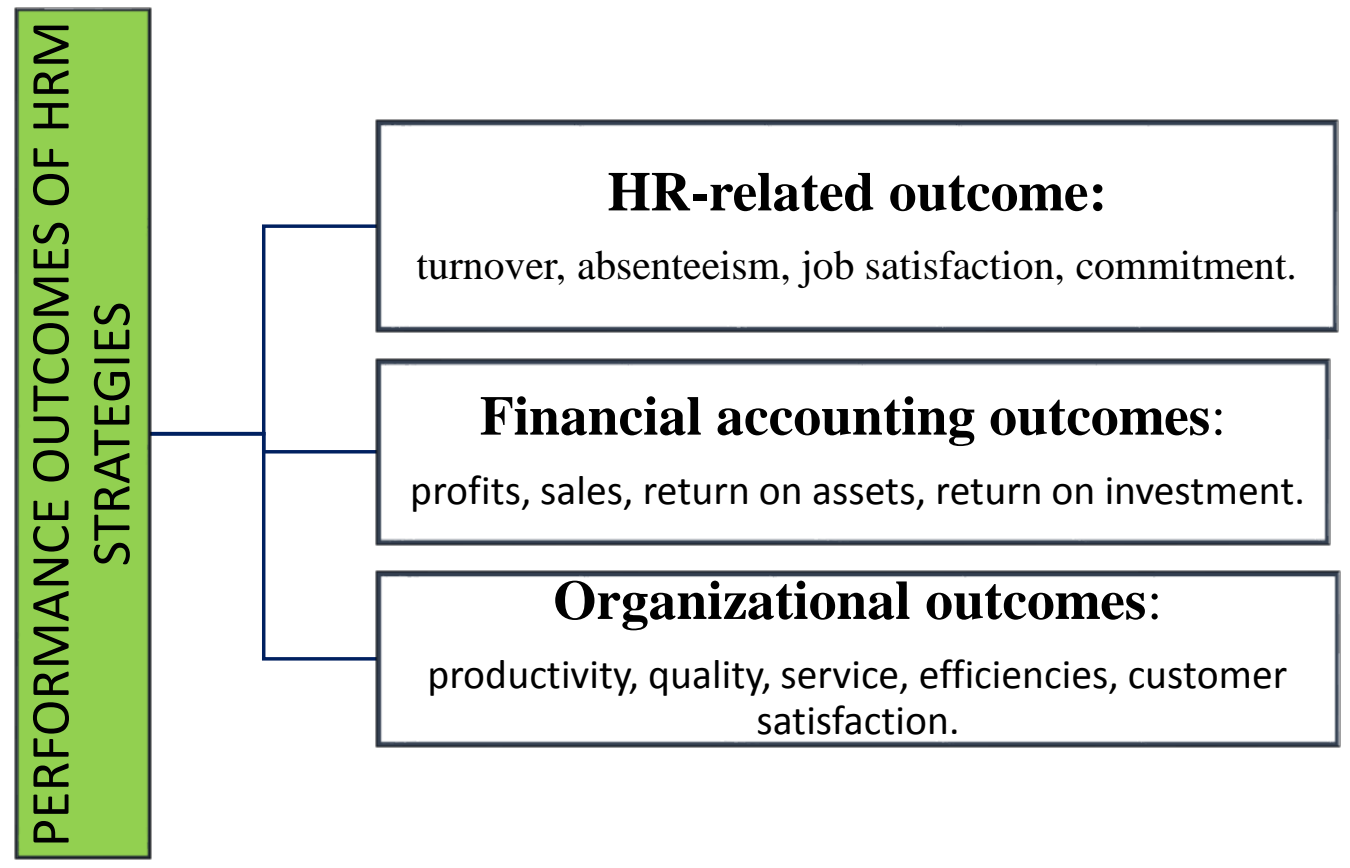

Figure 3. Performance Outcomes of HRM strategies

Source: Marvel, 2011

According to Dyer and Reeves (2009), "The success of a business depends on its human resources. The development and inspiration process of the workers in the organization plays an important role in the 
organizational success (Mondy, et al, 2015). Boxall, et al, (2007) said that his presupposes an integral approach toward human resource functions and overall business functions of anorganization. Thus, as mentioned by Harvey (2012) human resource strategies look at HR functions in line with the business strategies of an organization".

In a study, Mayo (2012) said that human resource strategies focus on the long-term people issues of an organization and helps in the creation of organizational structure. Long (2011) argued that these strategies are prepared to adapt changes like mergers, downturns, and acquisitions. The strategic human resource management emphasizes on the improvement of the ethics of the organization, as well as on evaluating the impacts that the business decisions of a company are going to play in the society at large.

Milkovich et al., (2011) considers "Human resources strategies help to achieve acompetitive advantage over other organizations. Farazmand, (2007) said that organizations are becoming aware and focusing on making effective human resource strategies which may increase performance in different areas such as productivity, quality, and financial performance".

According to Noe, et al, (2007) human resources strategies represent a transformation, which is relatively new in the field of human resource management. As mentioned by Delahaye (2011) an important role of strategic human resource management is about focusing the management in employees as a tool for achieving competitive advantage. Now, businesses are made cautious that successful human resources methods and practices can increase performance in various areas including productivity, quality, and financial performance.

A proper use of human resources will ensure the achievement of the objectives of the organization. The potential use of skills, knowledge and competencies of employees in the organization would help to improve organizational performance. Milkovich (2006) opined that basically, it is also confirmed by other research that strategic management of human resources has an impact on organizational performance. The study analyzed 30 organizations, which 16 organizations are the service sector and 14 organizations are in the manufacturing sector.

The study is focused on two sections. In the first section, the study is focused on the theoretical aspects of adoption of human resource strategies in organizations. While in the second section, the study focuses on the impact providing strategic management of human resources in organization performance.

Referring Figure 4, from the study of 30 organizations emerged that $26(87 \%)$ of them were familiar with the concepts and implementation of human resource management strategies in their organization. In simple words these business have a specific way for managing human resources. While 4 (13\%) of other business were not very familiar with the implementation of it. This means that these organizations do not have a human resources strategy. These organizations do not implement enough strategies, which mean that the required performance can be hard to achieve, the organization operates without studying environment.

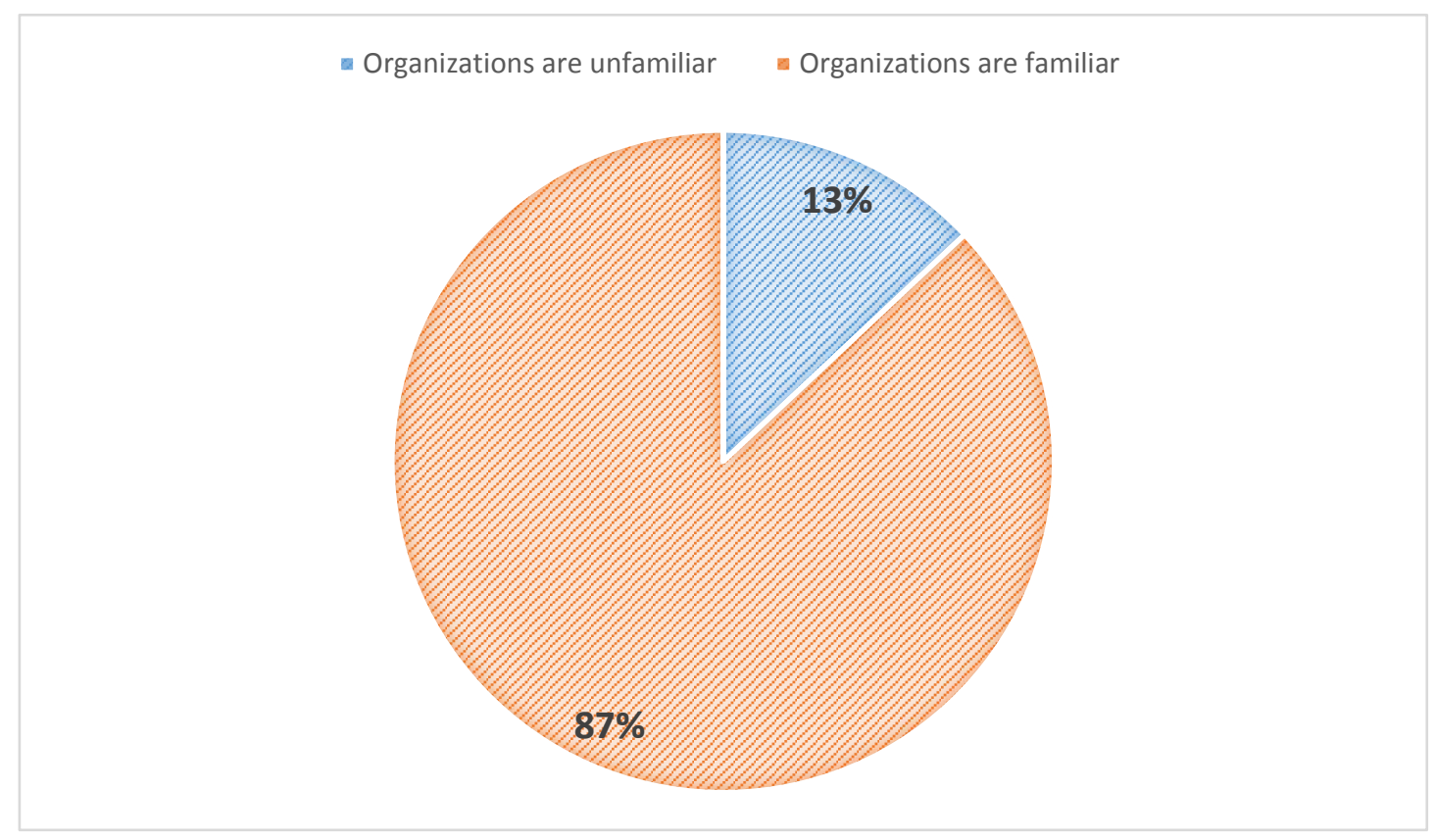

Figure 4. The Practical Implementation of Theoretical Knowledge 
In the second section, Strategic Human Resource Management is the planned pattern of human resource activities that intended to enable the organization to meet organizational goals and objectives. Some of the goals are cost minimization, achievinghigher sales levels, increasing the number of customers, increasing product quality, innovative products, improve productivity, increasing the market percentage etc.

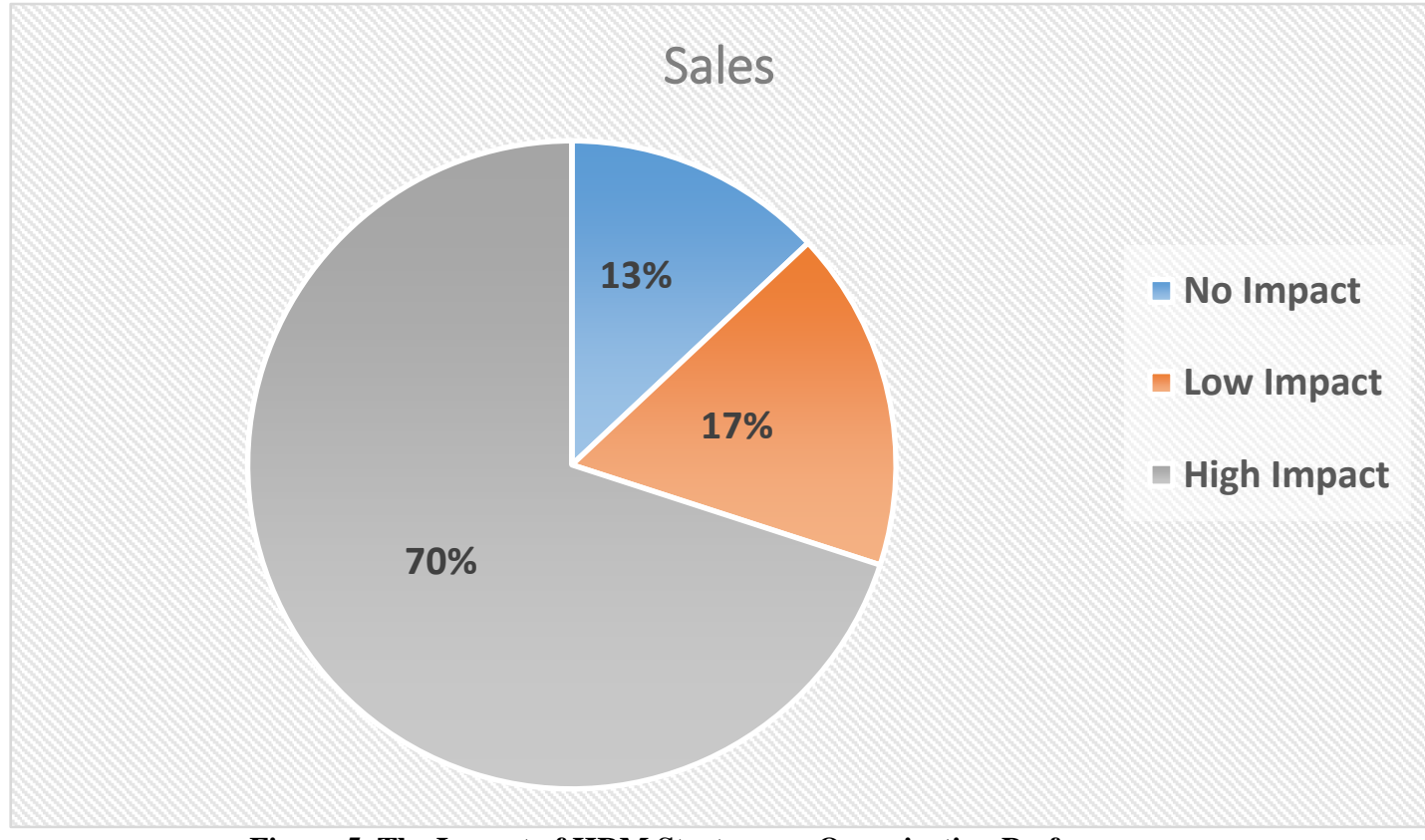

Source: Schmalz, 2012

Figure 5. The Impact of HRM Strategy on Organization Performance

According to Hazarika (2014) organizations choose one or several indicators and use them to measure their performance. For example, organizations decide as a measure of performance enhancing the quality of the product and increase the level of sales in the market. So, increase in product quality will enable improvement of sales by increasing profit (Campbell and Moyers, 2013). The organizations must manage its inputs to achieve their desired outputs. Torrington, et al, (2011) said that one of the vital inputs for the organization is human resource. Good human resource strategies will make possible the achievement of objectives. If we refer to the inputs of human resources it would be the knowledge, skills, behaviors and competencies. From the study of Boxall, et al, (2007) it emerged that 21 (70\%) organizations had proven significantly change their performance through strategic management of human resources. On the other hand, Huselid, et al, (2015) revealed that $16.7 \%$ organizations admitted that the organization had faced minor changes in their performance. These small changes are due to ineffective human resource strategies. According to Marvel (2011)13.3\%) organizations did not have any impact on the organizational performance by strategic human resource management. These organizations do not have a genuine business strategy and human resource management strategy.

After developing the HR strategy, the plan must be implemented. Oftentimes, companies spend time and money developing plans and then they are filed in a drawer and never utilized. The company has to create a viable HR strategy and can avoid this pitfall as well as can help their business improves.

If the HR strategy includes the objective of "Fulfill hiring needs of company" it would be impossible to determine if that goal had been met (Mondy, et al, 2015). Harvey (2012) said that changing the objective and writing "Filling 5 empty positions with qualified individuals to meet the requirement of the sales department", baseline is established for developments. It is then easy to maximize the success or failure of the objective. As suggested by Noe, et al, (2007) regular evaluation of success is essential to a detailed HR strategy. Regular need for evaluation and the potential need for change must be considered. Suppose sales figures indicate a need for incensement of staff. The HR department puts considerable effort into hiring the extra dozen people needed. According to Mondy, et al, (2015) when the company started to face trouble making the payroll, it is exposed that sales figures were overstated. Then the HR strategy will require to make quick changes. Observing legal requirements and regulations can also necessitate change through the implementation of new laws or mandates and affect business (Long, 2011). Farazmand (2007) stated that an increase in minimum 
wage may affect the budget as well as staffing needs of a company and require the company to make changes accordingly.

\section{Effective Implementation of Human Resource Strategies}

As stated above in the literature, human resource and its strategies has massive contributions on performance of the employees which gradually helping achieving organizational goals. So it is very important to implement the strategies in effective way. Three recommendations can be given regarding the effective implementation of human resource strategies:

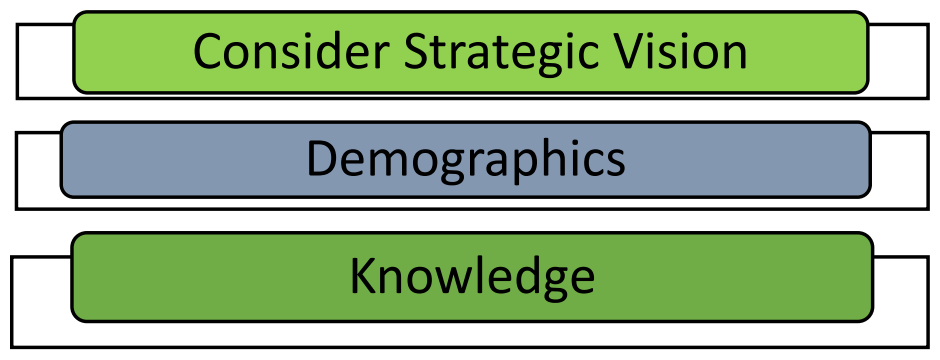

Figure 6. Recommendation of Effective Implementation of HR Strategy

Source: Dyer and Reeves, 2009

Consider Strategic Vision: HR strategies, which are effective, cannot survive in a vacuum. According to Milkovich (2006), they must be aligned with the organization's strategic vision. The vision will provide an indication of where the company is heading. Boxall, et al, (2007) it will also indicate how the people resources needed to help it get there. According to Prasad, et al, (2013) HR leaders should review the company's current vision and determine ways in which HR activities can support that vision. Like other organizational leaders, HR staff must consider whether the vision is applicable based on external as well as internal factors and whether changes in the marketplace may be suggesting a new vision.

Consideration of Demographics: As senior employees' approach retirement, organizations know that they will be faced with a lack of key staff members and in addition, an old man power population may show high staffing expense as well as the need for training and retraining (Hazarika, 2014). According to Schmalz (2012), HR leaders should examine the demographics of the workforce to determine the gaps exist between current skills as well as the requirement for skills that may need in $t$ future, in line with the organization's mission and strategies.

Transfer of Knowledge: Ensuring transfers of knowledge among department workers is necessary to ensure continuity as well as minimal impact on productivity and effectiveness (Torrington, et al, 2011). Huselid, et al, (2015) said that a strategy for transferring knowledge is critical and can be done through knowledge synchronization plans. These plans are designed make sure that the knowledge retired workersis captured as well as transferred to younger workers.

\section{Conclusion}

In current business world, organizations are trying to make competitive advantage in the industry and to manage their human resources in getting the organizational performance required. To achieve this mission, organizations are including cost reduction, attaining higher sales levels, Improving the number of customers, increasing the market share, increasing product availability, different products, focus in maximization of wealth. Human resources act as the most important thing in achieving theseperformance goals. But before that, organizations should understand the expectations required from employees as well as the employees show their skills, be motivated and behave in the manner required by the organization to achieve performance. Human resource strategy is an elaborative process for human resource management throughout the business that it's related with the total strategy of the organization. It helps the organization having employees with the accurate skills by putting them in situations according to the level of their qualification and skills. There is a strong link between Strategic human resource management and organizational performance and productivity (Venkatraman and Ramaunjam, 2007).

An efficient HR strategy can help an upcoming big company, but if it is not used properly, the HR strategy can be injurious to a company's overall health. Human resource strategies can be helpful in developing the goals as well as new projects of a company. It is important to include the company's goal in the development of the HR policy and trying to implement one without the other can lead to disgruntled and misguided employees (Wright and Cummings, 2013). An HRM manager should refer to the total strategic planfor 
developing the HRM strategic plan. If a company does not have an HR department, HRM strategic plans should be implemented by management. By developing and exploring these plans, the organization can make sure the right processeswhich are in proceed to meet the ever-changing necessity of the organization. The strategic plan looks at the organization as a whole, and the HRM strategic plan looks at the department as a whole.

An organization should develop an effective HR strategy by studying best practice methods used by other companies within the industry. Creating a responsive HR strategy requires diligence and work. Establishing the vision of the company, developing the role of the HR department and creating a workforce plan for the company are all part of the ways the strategy is designed. Creating and making sure, the plan and then evaluating the success of the strategy are crucial to stimulate production as well as the overall organization performance.

The current paper is been produced based on the secondary data specifically different literature, articles and book recommendations to justify how strategic human resource practices can be handy in achieving organizational goals, but it is true that not all the organizations are same in size, financial growth, management style and most importantly they may not be from the same geographical location which follows same culture. So, the recommended strategies may not be a true reflection for every organization but an overall idea. To assess the most accurate strategies for a particular organization, there are still many scopes for the future research targeting organizational size, financial growth, management style, culture and geographical location.

\section{References}

1. Armstrong, M. and Armstrong, M. (2009). Armstrong's handbook of human resource management practice. London: Kogan Page.

2. Becker, B. and Gerhart, B. (1996). The impact of human resource management on organizational performance: Progress and prospects. Academy of Management Journal, 39, 779-801.

3. Boxall, P., Purcell, J. and Wright, P. (2007). The Oxford handbook of human resource management. Oxford: Oxford University Press.

4. Campbell, J. and Moyers, B. (2013). The power of myth. New York: Doubleday.

5. Delahaye, B. (2011). Human resource development. Prahran: Tilde University Press.

6. Delery, J. E. and Doty, D. H. (1996). Modes of theorizing in strategic human resource management: Tests of universalistic, contingency, and configurational performance predictions. Academy of management Journal, 39(4), 802-835

7. Dyer, L. and Reeves, T. (2009). Human resource strategies and firm performance. Ithaca, NY: Center for Advanced Human Resource Studies, Cornell University, ILR School.

8. Farazmand, A. (2007). Strategic public personnel administration. Westport, Conn.: Praeger Publishers.

9. Guest, D. E. (1987).Human Resource Management and Industrial Relations. Journal of Management Studies, 24(5), 503-521.

10.Harvey, D. (2012). Business policy and strategic management. Columbus, Ohio: C.E. Merrill Pub. Co.

11.Hazarika, S. (2014). Managing Human Capital: A Performance Exploration. SSRN Electronic Journal.

12.Holbeche, L. (2004). How to make work more meaningful. Personnel Today, 26.

13.Huselid, M., Becker, B. and Beatty, R. (2015). The workforce scorecard. Boston, Mass.: Harvard Business School Press.

14.Huselid, M. A. (1995). The impact of human resource management practices on turnover, productivity, and corporate financial performance. Academy of management journal, 38(3), 635-672.

15.Long, R. (2011). Commentary: Social Exchange in Building, Modeling, and Managing Family Social Capital. Entrepreneurship Theory and Practice, 35(6), 1229-1234.

16.Marvel, M. (2011). Human Capital and Search-Based Discovery: A Study of High-Tech Entrepreneurship. Entrepreneurship Theory and Practice, 37(2), 403-419.

17.Mathis, R., Jackson, J.H. (2008). Human Resource Management. 12th ed. Cengage Learning.

18.Mondy, R., Noe, R. and Gowan, M. (2015). Human resource management. Upper Saddle River, N.J.: Pearson Prentice Hall.

19.Noe, R., Hollenbeck, J. and Gerhart, B. (2007). Human resource management. Chicago: Irwin.

20.Schmalz, M. (2012). Managing Human Capital Risk. SSRN Electronic Journal.

21.Torrington, D., Hall, L. and Torrington, D. (2011). Human resource management. London: Prentice Hall Europe.

22.Walton, J. (1999). Strategic Human Resource Development, London: Financial Times.

23.Wright, R. and Cummings, N. (2013). Destructive trends in mental health. New York: Routledge. 